\title{
MATHEMATICAL MODELS FOR STUDY AND AsSESSING OF AdHESIVE MECHANICAL AtTrition Process of Coupling Elements IN SLIDING FRICTION
}

\author{
UnGUR, P.; POP, P.A.; GORDAN, M.; GORDAN, C. \& POP, M.T.
}

Abstract: In paper has presented certain opinions and appreciations about of quadratic mathematical functions of friction, derivate from classical concept of Lorentz attrition curve, for adhesion attrition in time of coupling elements sliding friction. The Lorentz wear curve $W=f(t)$ presents the evolution of third equation on range-OABC. This curve has an inflexion point and included a running in zone-OA, a stability zone-AB and damage zone-BC. The new concept given other interpretations of wear functions $W=f(B, S)$ and $W=f(t)$, being description as parabolic functions in time and a parabolic function of wear in time for running in and stability wear. These have known as normal wear, with gradient of wear curve a parabola with top in origin and symmetry axe-Ot horizontal with ascendant shape of curve in running in period-OA, and low ascendant aspect on $A B$ curve for stability wear, the function has a parabolic equation.

Key words: attrition, contact, friction, parabola, sliding
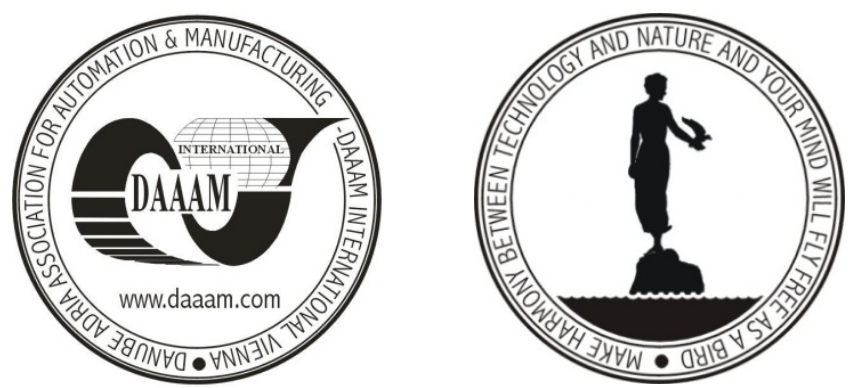

Authors' data: Prof. PhD. Ungur, $\mathrm{P}$ [etru]; Assoc. Prof. PhD. Pop, P[etru] A[drian]; Prof. PhD. Gordan, M[ircea]; Prof. PhD. Gordan, C[ornelia]; Prof. PhD. Pop, M[ircea], University of Oradea, 1 University Str.,, 410087, Oradea, RO, petru_ungur@yahoo.com,_ petruapop@rdslink.ro, cgordan@uoradea.ro,popmt@uoradea.ro

This Publication has to be referred as: Ungur, $\mathrm{P}[\mathrm{etru}$; Pop, $\mathrm{P}$ [etru] A[drian]; Gordan, M[ircea]; Gordan, C[ornelia] \& Pop, M[ircea] (2008). Mathematical Models for Study and Assessing of Adhesive Mechanical Attrition Process of Coupling Elements in Sliding Friction, Chapter 73 in DAAAM International Scientific Book 2008, pp. 891902, B. Katalinic (Ed.), Published by DAAAM International, ISBN 978-3-901509-66-7, ISSN 1726-9687, Vienna, Austria

DOI: $10.2507 /$ daaam.scibook.2008.73 